\title{
Sedimentary succession of the Lower Cretaceous deposits from the north-western part of Pădurea Craiului (Apuseni Mountains, Romania)
}

\author{
Daniel F. LAZĂR¹, Ioan I. BUCUR ${ }^{1 *}$, Ioan COCIUBA ${ }^{2} \&$ Emanoil SĂSĂRAN1 \\ ${ }^{1}$ Department of Geology, Babeş-Bolyai University, Kogălniceanu 1, 400084 Cluj-Napoca, Romania \\ ${ }^{2}$ Geological Institute of Romania, Cluj-Napoca branch, Plopilor 54, 400379 Cluj-Napoca, Romania
}

Received January 2012; accepted February 2012

Available online 7 February 2012

DOI: $10.5038 / 1937-8602.56 .2 .4$

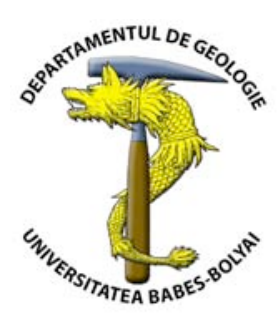

\begin{abstract}
Within the general succession of the Lower Cretaceous deposits from the Vârciorog-Dobreşti area (Pădurea Craiului Mountains), carbonate and terrigenous deposits were identified. The limestones were assigned to two distinctive lithostratigraphic units: the Valea Măgurii and Vârciorog formations. Based on the orbitolinids Palorbitolina lenticularis and Mesorbitolina texana their ages are assigned to the early Aptian, and respectively late Aptian-Albian. The terrigenous facies mainly include fine-grained deposits (clays, siltites, marls) and, to a lesser extent, coarser ones (glauconitic sandstones and conglomerates), and they are attributed to the Ecleja and Vârciorog formations. The marls of the Ecleja Formation have been observed in a single section. The lack of fossils prevents assigning an age to this marl succession. Based on their relative location, i.e., at the base of the late Bedoulian Valea Măgurii Limestones, they may be assigned to the early Aptian (early Bedoulian). The siliciclastic deposits of Vârciorog Formation cover the largest areas in the region. Their late Aptian-Albian age is established based on the presence of Mesorbitolina texana. Additional arguments are represented by an ammonite fauna assigned to the terminal Bedoulian-early Gargasian. This fauna is located at the base of the Vârciorog Formation. The Lower Cretaceous deposits cropping out in this area have been investigated in seven geological sections. The data interpretation allowed a synthetic reconstruction of the succession and of the depositional environments.
\end{abstract}

Key words: Lower Cretaceous, microfacies, microfossils, Apuseni Mountains, Pădurea Craiului, Romania.

\section{INTRODUCTION \& GEOLOGICAL SETTINGS}

The area under study is located in the north-western part of Pădurea Craiului, Northern Apuseni Mountains, Romania (Fig. 1). Previously, Szontagh (1904), Fisch (1924), Kräutner (1939, 1941), Răileanu (1956), Preda (1963), Patrulius (1956), Bordea and Istocescu (1970), Istocescu (1970), Popa (1981), or Patrulius et al. (1982) have published aspects concerning the Lower Cretaceous deposits in the Pădurea Craiului Mountains. Studies on micropaleontological associations and lithostratigraphical units here were published by Dragastan (1966), Bucur (1981a, 1981b, 1985), Dragastan et al. (1986), Bucur (1988), Dragastan et al. (1988), Bucur (1992, 1995), Bucur et al. (1993), Bucur and Cociuba (1996, 1998), Cociuba (1995, 1997), Dragastan (1999) and by Dragastan and Ciobanu (2002). The most recent contributions on the lithostratigraphy of the Lower Cretaceous in this area belong to Cociuba (1999, 2000), Bucur and Cociuba (2001) and Bucur et al. (2008, 2010).

Our contribution represents the first detailed study of the Lower Cretaceous deposits in the Vârciorog-Dobreşti area (northwestern part of the Pădurea Craiului Mountains). The area under study has a complex structure and the detailed geological setting is still not completely defined. Here we use the lithostratigraphical units separated by Bucur and Cociuba (1996), Cociuba (1999, 2000), and Bucur and Cociuba (2001) (Fig. 2):
1. Blid Formation (Dragastan et al., 1986, 1988). Cociuba $(1999,2000)$ has separated two members within this formation:

1a. Dobrești Member, locally containing bauxite in the base, situated on the top of the Upper Jurassic limestones. This calcareous member has a lacustrine origin, and was previously named as "The limestone with characeans and gastropods" (Patrulius, in Ianovici et al., 1976). Some marine levels interlayered within the limestones with characeans contain dasycladalean algae and foraminifers attributed to the Valanginian-?Hauterivian interval (Bucur, 2000).

1b. Coposeni Member, originally defined as „Lower limestone with pachyodonts" (Patrulius, in Ianovici et al., 1976). Based on the foraminifer associations identified in its lower third part containing, among others, Paracoskinolina? jourdanensis, this level was assigned to the Barremian (Bucur et al., 1993).

2. Ecleja Formation (Patrulius in Ianovici et al., 1976) is a blackish to greyish silty marl succession; besides marls, it comprises two other members with distinct lithologies (Cociuba, 1999, 2000):

2a. Gugu Breccia Member (Patrulius et al., 1982) consisting of compact calcareous breccia with calcareous or terrigeneous matrix.

2b. Valea Bobdei Limestone Member (Cociuba, 1999, 2000), partly encompassing the former „Middle limestone with pachyodonts" (Patrulius in Ianovici et al., 1976). 


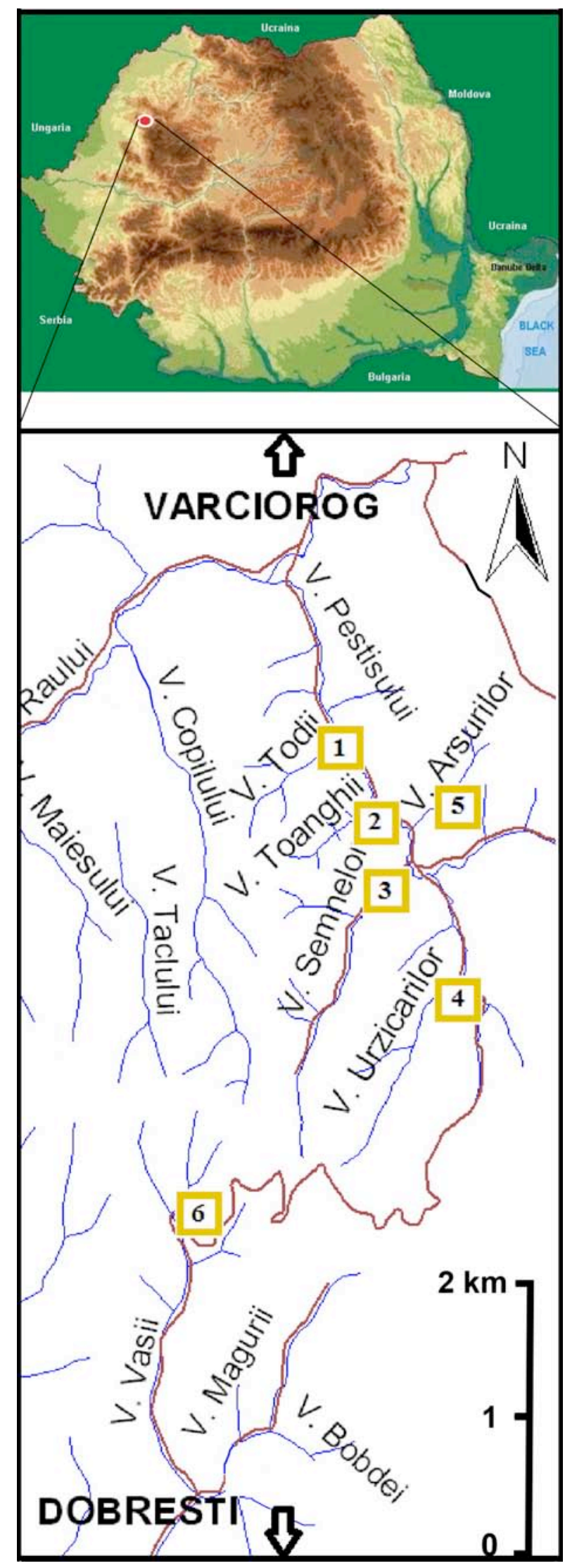

Fig. 1. Location of the six investigated geological sections within the Vârciorog-Dobrești area.

This member consists of a stratified succession of metrethick layers of grey or greyish-blackish limestones, very rich in foraminifers such as Sabaudia capitata Arnaud-Vanneau, Voloshinoides sp., ?Archaealveolina sp., Paracoskinolina hispanica, Salpingoporela sp., Palorbitolina lenticularis Studia UBB Geologia, 2012, 57 (1), 33 - 51

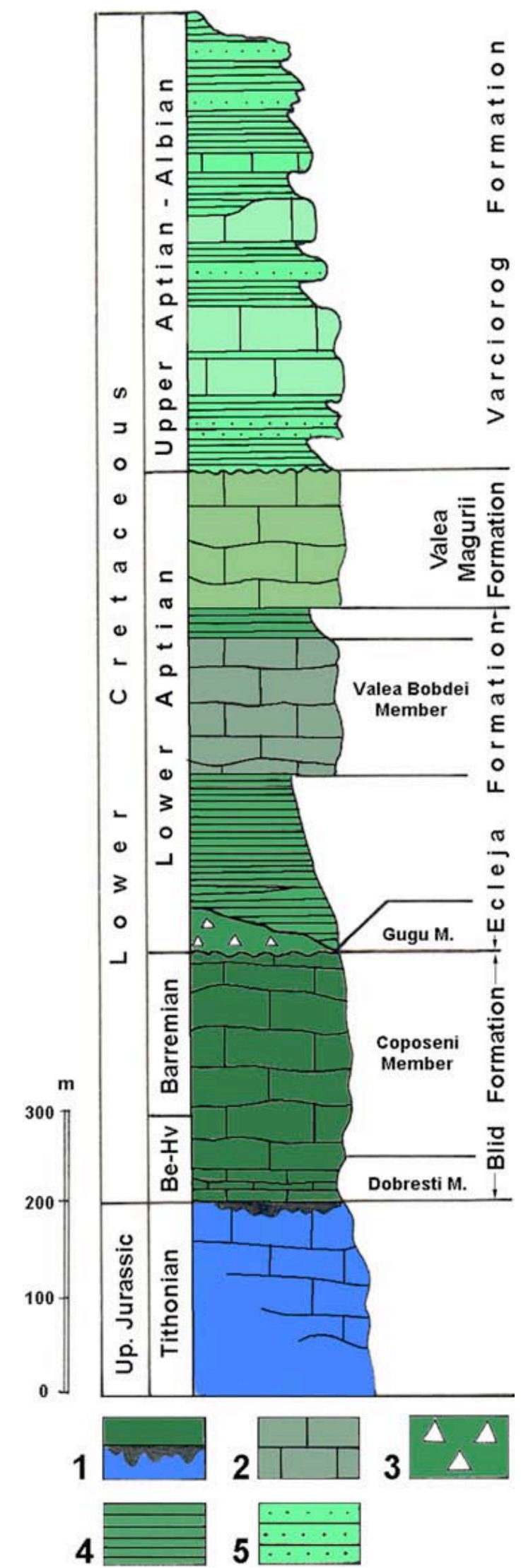

Fig. 2. Succession of the Lower Cretaceous deposits from Pădurea Craiului mountains (after Bucur and Cociuba, 2001).

(Blumenbach). This foraminiferal association points to a Lower Aptian (Lower Bedoulian) Age.

3. Valea Măgurii Formation (Cociuba, 1999, 2000). This entirely calcareous formation unconformably lies on the top of Ecleja Marls. The light grey limestones form decimetre-thick 
levels and they are rich in foraminifers, algae and rudists. Macroscopically, the Valea Măgurii Limestones are very similar to the limestones of the Blid Formation and the Valea Bobdei Member. They partially overlap the previously defined "Middle Limestones with pachyodonts" (Patrulius in Ianovici et al. 1976). The micropaleontological association includes: Orbitolinopsis cuvillieri Moullade, Orbitolinopsis buccifer Arnaud-Vanneau, Orbitolinopsis kiliani Silvestri, Palorbitolina lenticularis (Blumenbach), Salpingoporella muelbergi (Lorenz), and Pseudoactinoporella fragilis Conrad. This association indicates an early Aptian (most probably late Bedoulian) age.

4. Vârciorog Formation (Cociuba, 1999, 2000) corresponds to the ,complex of glauconitic sandstones and upper limestones with pachyodonts" (Patrulius in Ianovici et al., 1976). In the Vârciorog area, this formation is represented by a succession of siltic, clayey, marly and carbonate [blackish nodular limestones with Mesorbitolina texana (Roemer)] deposits that unconformably overlie the Valea Măgurii Formation. Avram et al. (2001) have described a uppermost Bedoulian-basal Gargasian ammonite fauna with Toxoceratoides stefanescui Avram, Helicancylus aequicostatus (Gabb), Acrioceras sp. ex gr. A. sarasini Sarkar, Dufrenoya cf. lurensis (Kilian), Colombiceras (C.) cf. tobleri (Jacob \& Tobler), Colombiceras (C.) cf. tobleri discolidalis (Sinzow), Colombiceras (C.) cf. subpeltoceratoides (Sinzow), C. (Egoianiceras) cf. multicostatum Avram, Pseudohaploceras cf. matheroni (d'Orbigny), and Hamiticeras cf. pilsbryi Anderson. This fauna was identified in the basal deposits of the Vârciorog Formation, in both the area of the quarry in the Măgurii Valley (a left tributary of the Văsii Valley) as well as in the left bank of Văsii Valley close to the junction with the Măgurii Valley. Unfortunately, with one exception mentioned in a footnote, the authors erroneously located this fossiliferous level on the top of the "lower limestones with pachyodonts" (= Coposeni Member) instead of the "middle limestones" (= Valea Măgurii Formation), as it is the case in the profiles. Based on the presence of Mesorbitolina texana (Roemer), a late Aptian-Albian age was assigned to the Vârciorog Formation.

A "red detrital formation" overlies the Lower Cretaceous deposits, as the last term of the Cretaceous succession, right below the overthrust plane of the Arieşeni Nape covering the Bihor autochtonous deposits of the region. Currently, only a few fossil remains have been identified within the "red formation"; they were assigned to several planktonic foraminifers: Hedbergella britonensis Loeblich \& Tappan, Praeglobotruncana delrioensis (Plummer), Globotruncana lapparenti Brotzen, and Rotalipora montsalvensis Monrod. Most the previous authors (Istocescu, 1970; Istocescu et al., 1970; Bleahu et al., 1971) have attributed this fauna to the Cenomanian-middle Turonian interval.

\section{FIELD DATA AND RESULTS}

\section{Short description of the sections}

\section{Todii Valley Section}

This section is located in the Todii Valley, a right tributary of the Peştisului Valley, very close to the Vârciorog locality (Fig. 1).
Grayish carbonate deposits represented by bioclastic limestones build-up the lower part of the succession (Fig. 3).
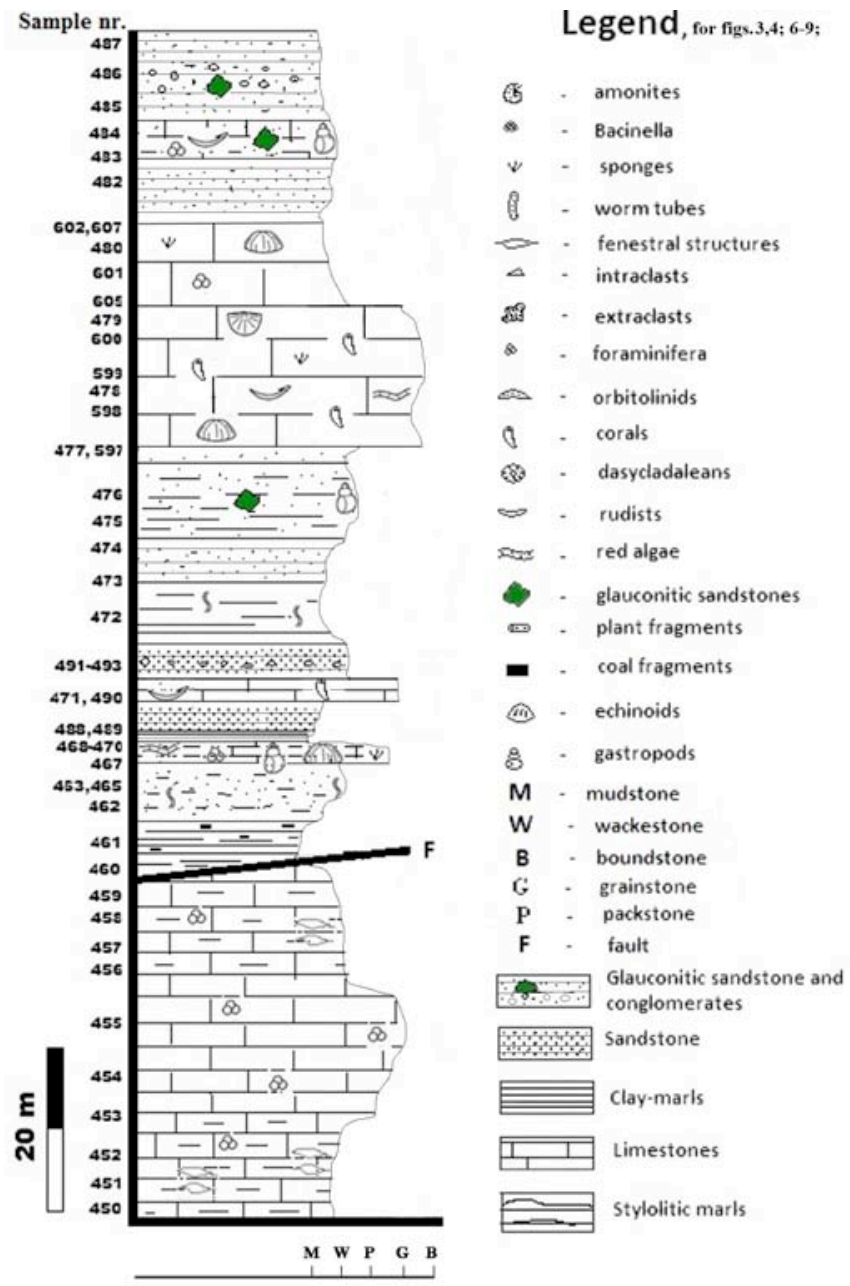

Fig. 3. Succession of the Lower Cretaceous deposits from the Todii Valley section.

The most representative microfacies are fenestral mudstone/ wackestone (Pl. I, Fig. 2), bioclastic wackestone, wackestone and peloidal bioclastic packstone/grainstone (Pl. I, Fig. 6).

Foraminifers (miliolids, Nezzazatinella sp., ?Arenobulimina sp. (P1. III, Fig. 3), Meandrospira sp., Textularia sp., Vercorsella sp.) and less frequently calcareous algae (Salpingoporella sp.) are the dominant components of the corresponding micropaleontological association. In addition, we have identified fragments of bivalves and peloids. Both the microfacies types and the microfossils are typical for the Valea Măgurii Formation (the upper part of the lower Aptian, or the upper Bedoulian, cf. Bucur and Cociuba, 2001).

A NW-SE oriented fault interrupts this succession. On the top of the fault, alternating siliciclastic and carbonate sediments were deposited.

The siliciclastic deposits are located in the middle and upper part of the succession (Fig. 3). They consist of a complex interlayering of fine deposits (micrites/marls) and coarser levels of conglomerates/carbonatic or siliciclastic sandstones. The bioclastic sandstones show tabular and layered geometries, while the conglomerates usually form lenses. The pebbles within the conglomerates and microconglomerates are mainly represented by rounded metamorphic clasts (quartzites, micaschists, chloritic or other types of schists, and recrystallized limestones). 
Besides the pebbles, other components of the deposits are large bioclasts of rudists, corals, gastropods and benthonic foraminifers (orbitolinids). As a rule, the conglomerates are poorly sorted, with the ruditic clasts chaotically distributed in a bioclastic arenitic matrix.

Along the whole succession, the unchannelled bodies with tabular or layered geometries represent the most frequent "coarse"-type deposits interlayered within the finer sediments. They are centimetre- to decimetre in thickness, and cover tens of meters in length. We have identified erosional structures at their base. The bodies present normal/reverse grain-sorting and horizontal laminations, and they consist of a fine carbonatic or siliciclastic material, the size of the clasts ranging from fine sand to silt. Carbonate intraclasts, bioclasts (frequent echinoid plates, bryozoans and benthic foraminifers), extraclasts mainly of metamorphic (schists and recrystallized limestones) or of sedimentary (clays/marls) origin, compose the infilling of the granular sand bodies.

Both in the sandstones and in the matrix of the conglomerates we have recognized fragments of rudists and corals, coal (vegetal) remains, bryozoans, gastropods, echinoid plates and radioles, cyanobacteria and benthonic foraminifers (orbitolinids) (P1. II, Figs. 7, 8).

The carbonate deposits consist of bioaccumulated or bioconstructed limestones (coral, or rudist and coral bioconstructions). The microfacies types identified in the bioaccumulated limestones vary from bioclastic wackestone/packstone to packstone/grainstone (Pl. II, Fig. 2) with orbitolinids, encrusting organisms or rudists, and additionally with terrigenous detrital material. The bioclasts are represented by rare fragments of algae, sponges, corals, gastropods, bryozoans, worm tubes, and fragments of crabs (Carpathocancer sp.). Foraminifers were also identified [Lenticulina sp., Mesorbitolina texana (Roemer) (Pl. IV, Fig. 8) and other agglutinated foraminifers].

Towards the top of the section, we have identified a 22-m thick calcareous succession consisting of bioconstructions of corals and rudists (Pl. II, Figs. 2, 5), sometimes encrusted by red algae. At the base of the limestones glauconitic sandstones crop out, containing fragments of corals, gastropods, and orbitolinids. The bioconstructions are mainly built up of coral colonies typically showing a branched growth fabric. Colonies developing lamellar/layered growth fabrics are less frequent. The internal sediment is represented by bioclasts mudstone/wackestone or by clayey siltites with fragments of corals, rudists and orbitolinids.

From the limestones in the upper part of the succession (samples 477-480 and 596-607 in Fig. 3) we have identified a macrofauna consisting of sponge fragments, corals (Microsolena sp., Cyathophora sp., Calamophylliopsis sp.), rudists, worm tubes (Terebella sp.), brachiopods, bivalves and echinoderms. The micropaleontological association consists of foraminifers [Sabaudia minuta (Hofker), Charentia cuvillieri Neumnn Meandrospira sp., Vercorsella sp., Everticyclammina sp., Nezzazatinella sp., Debarina sp., Textularia sp., Novalesia producta (Magniez), Gaudryina sp.], calcareous algae [Triploporella sp. (P1. IV, Fig. 2), Sporolithon rude (Lemoine), Marinella lugeoni Pfender, Polystrata alba (Pfender)] and rivulariacean-type cyanobacteria. Additionally, Bacinella irregularis Radoičić and Lithocodium aggregatum Elliott, as well as Carpathoporella occidentalis Dragastan ( $\mathrm{Pl}$. IV, Fig. 1) and crab fragments (Carpathocancer sp.) were recognized.

Studia UBB Geologia, 2012, 57 (1), 33 - 51

\section{Toanghii Valley Section}

The Toanghii Valley represents a left tributary of the Peştişului Valley located south of the Todii Valley (Fig.1).

The base of the succession is represented by coral bioconstructions alternating with bioclastic wackestone/packstone and/or bioclastic-extraclastic packstone/floatstone (Fig. 4).

\section{Sample nr.}

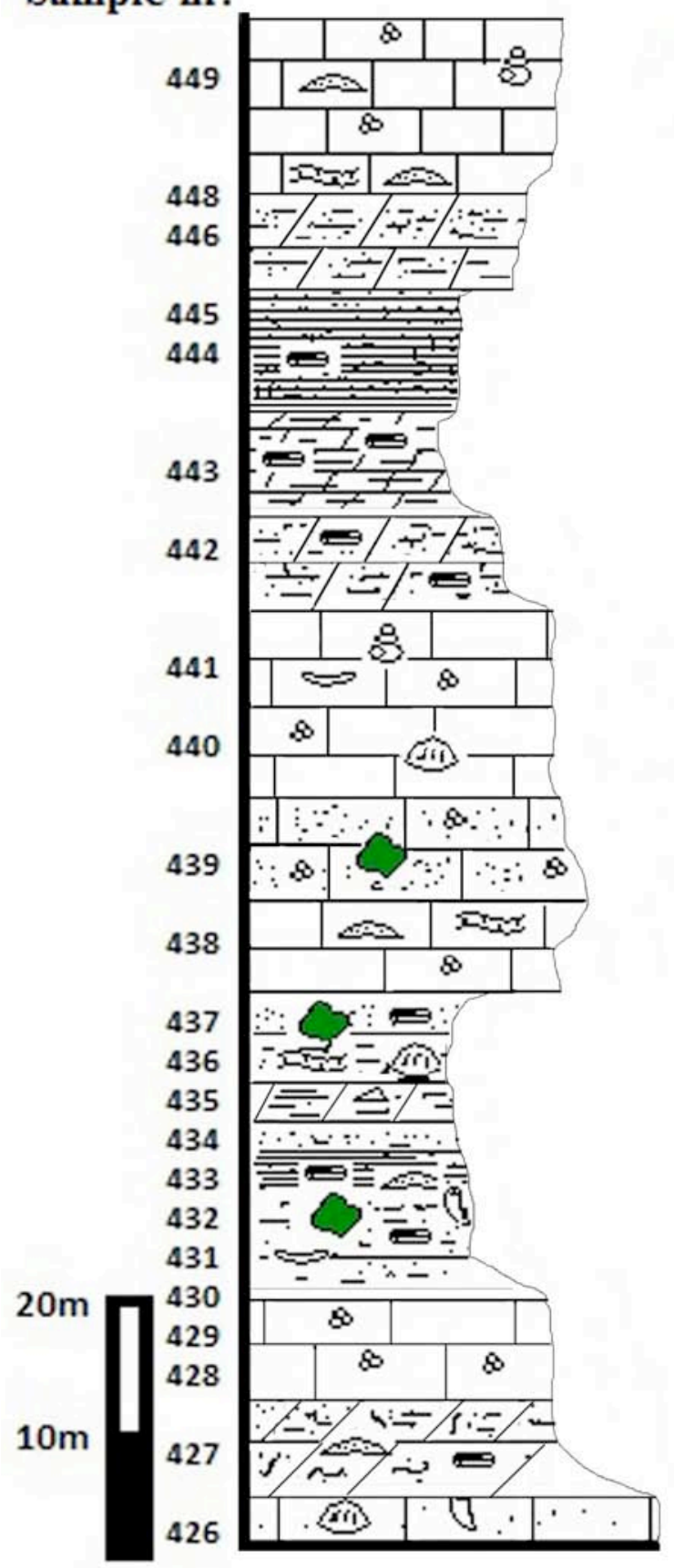

$\begin{array}{lllll}\mathbf{M} & \mathbf{W} & \mathbf{P} & \mathbf{G} & \mathbf{B}\end{array}$

Fig. 4. Succession of the Lower Cretaceous deposits from the Toanghii Valley section.

Within the bioconstructions the internal sediment is represented by bioclastic-extraclastic packstone. The most representative bioclasts are foraminifers, corals, fragments of bivalves, gastropods, bryozoans and echinoderms.

The next in the succession is a level of marls and carbonate sandstones with orbitolinids and ooids. They are followed by limestones represented by bioclastic 
wackestone/packstone (P1. II, Fig. 1) with frequent textulariid agglutinated foraminifers, miliolids and other foraminifers such as Charentia nana Arnaud-Venneau, Charentia cuvillieri Neumann and Nezzazatinella sp.

The calcareous level located in the middle part of the section consists of bioclastic packstone with Marinella lugeoni Pfender (Pl. IV, Fig. 3), Rivularia sp., Mesorbitolina texana (Roemer) (Pl. II, Fig. 4), Mesorbitolina subconcava (Leymerie), and textularrid agglutinated foraminifers. This is followed by a level of calcareous sandstones with orbitolinids and bivalve fragments that, towards the top, gradually passes into bioclastic wackestone/packstone with gastropods, rudists, Lithocodium aggregatum Elliott, Carpathoporella occidentalis Dragastan, fragments of echinoderms and corals.

The last calcareous level of this section crops out upstream the valley. It is represented by greyish-blackish bioclastic packstone with ooids, foraminifers, gastropods and red algae. The most abundant microfossils are Mesorbitolina sp., Charentia cuvillieri Neumann Everticyclammina sp., and Polystrata alba (Pfender).
Siltic marly or clayey rocks, sometimes finely laminated, with bioturbations and vegetal fragments are interlayered in between the calcareous levels. The bioclasts are represented by fragments of gastropods and rudist shells. The deposits cropping out along the Toanghii Valley are assigned to the Vârciorog Formation.

\section{Semnelor Valley Section}

The Semnelor Valley is located between the Toanghii Valley (north) and the Urzicarilor Valley (south) and represents the major left tributary of the Peştişului Valley (Fig. 1).

Three calcareous levels were intercepted in the profile along the Semnelor Valley (Fig. 6). The basal level crops out $150 \mathrm{~m}$ upstream from the junction with the Peştişului Valley, right at the junction with the first left tributary. This level is $30 \mathrm{~m}$ thick and it consists of bioconstructed black limestones (Fig. 5). The bioconstructions consist of corals, sponges (Pl. II, Fig. 6) and rudists encrusted by calcimicrobes and red algae.
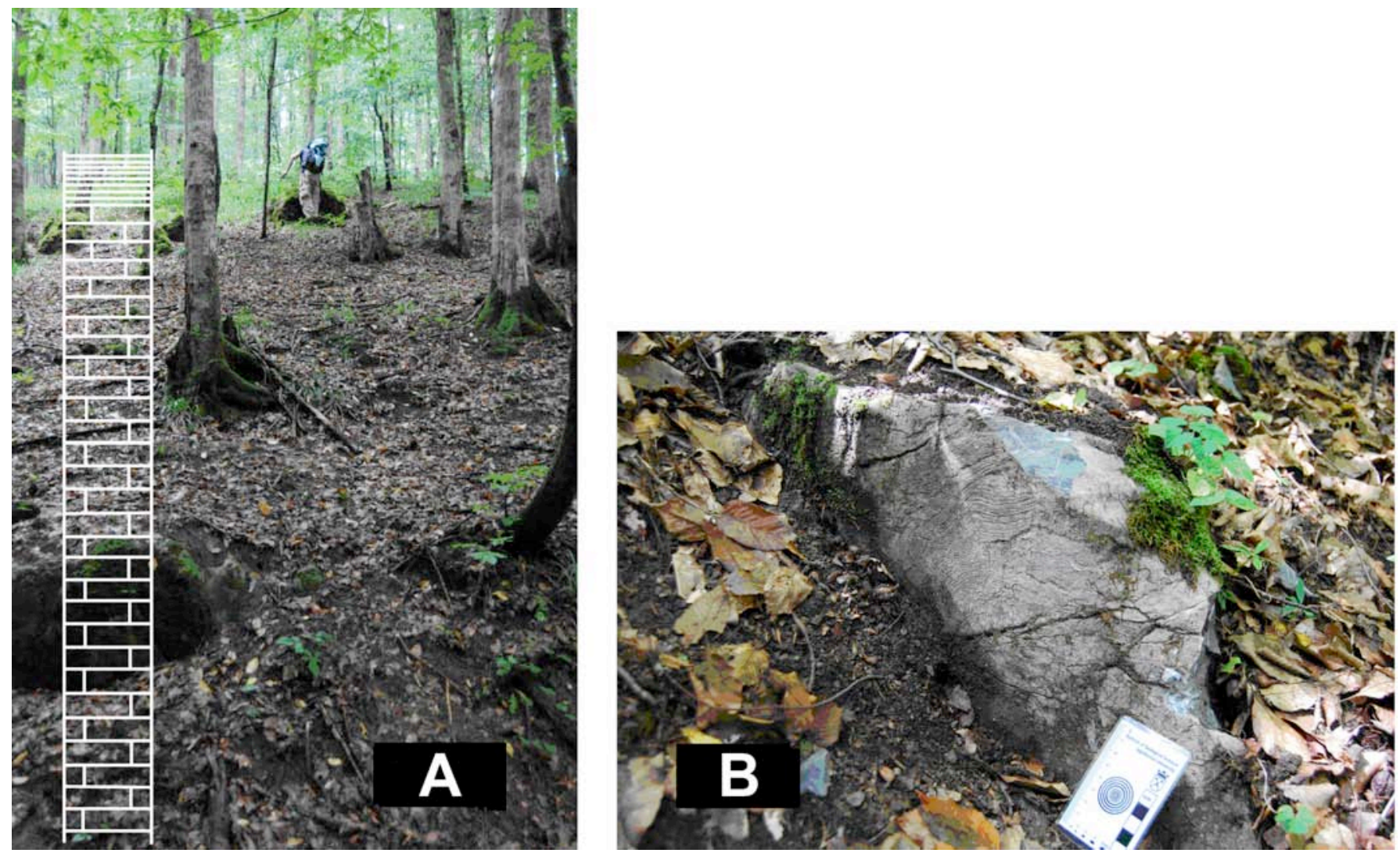

Fig. 5. Lower Cretaceous deposits from the Semnelor Valley. A) coral limestones, followed by marls and sandstones (Vârciorog Formation); B) Close-up view of the coral limestone level.

The micropaleontological association consists of foraminifers [Mesorbitolina texana (Roemer), Sabaudia minuta (Hofker), Charentia cuvillieri Neumann Charentia nana Arnaud-Vanneau, Rectocyclammina sp., Everticyclammina sp., Debarina sp., Dobrogelina sp. (P1. IV, Fig. 4), Bolivinopsis, sp., Textularia sp., Quinqueloculina sp., Gaudryina sp., Nezzazatinella sp.] and calcareous algae [Sporolithon rude (Lemoine), Polystrata alba (Pfender), Marinella lugeoni Pfender, Triploporella sp., Permocalculus sp., Solenopora sp., Rivularia sp.]. Additionally, we have evidenced the presence of Bacinella irregularis Radoičić, Lithocodium aggregatum
Elliott, Carpathoporella occidentalis Dragastan, crab (Carpathocancer sp.) fragments, worm (Terebella sp.) tubes, echinoid spines, bryozoans, fragments of brachiopods and bivalves.

The second calcareous level is $3-4 \mathrm{~m}$ thick and is separated from the previous one by a bioturbated marly clayey succession (samples 415-417) (Fig. 6). It displays similar facies types with the first limestone level: the same bioconstructors and an abundant foraminiferal fauna mainly represented by orbitolinids. Among the microfossils, we have identified Mesorbitolina texana (Roemer), 
Nezzazatinella sp., Lenticulina sp. (P1. IV, Fig. 8), Marinella lugeoni Pfender, and Bacinella irregularis Radoičić.

The third calcareous level is located in the upper part of the section. It is interlayered within the glauconitic sandstones horizon. These limestones contain orbitolinids, fragments of green algae, echinoderms and gastropods.

Nevertheless, most of the succession in this profile consists of (glauconitic) marly, sandy deposits. The fossil assemblage is sparse and consists of orbitolinids, gastropod fragments, bryozoans, rudist fragments, worm tubes and plant remains occur sporadically. The whole succession is assigned to the Vârciorog Formation.

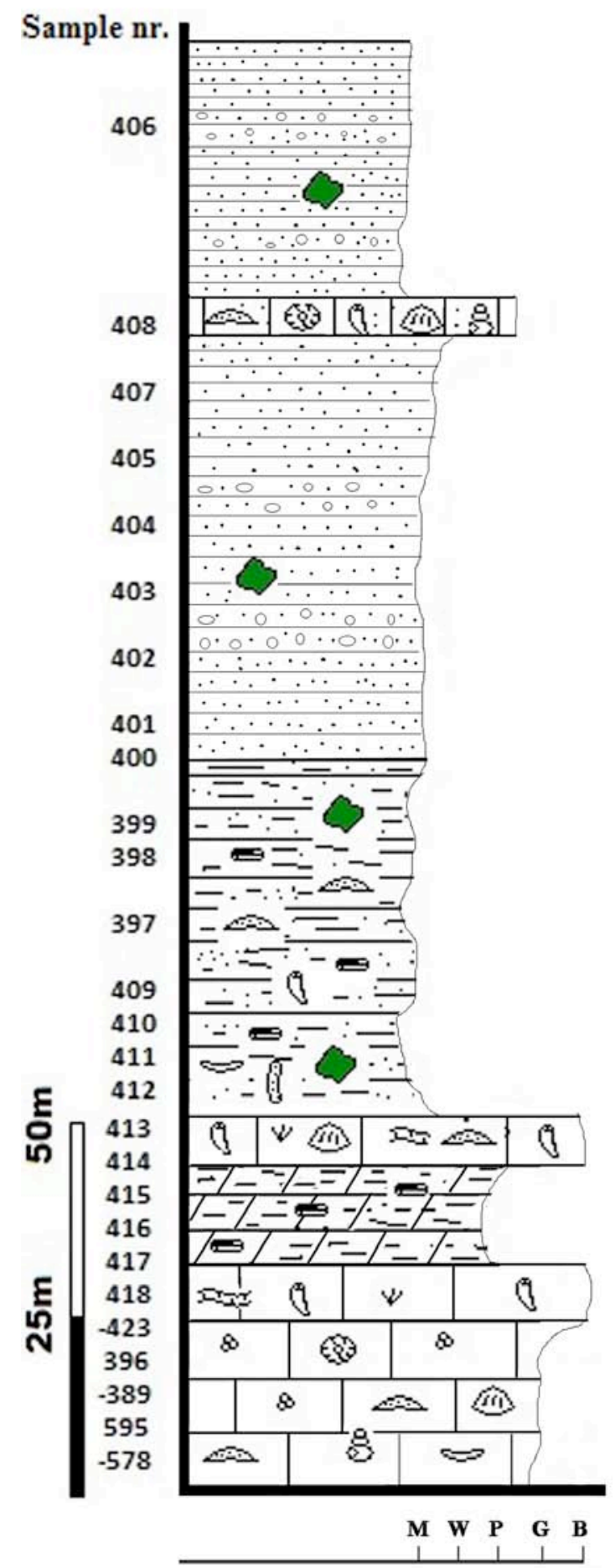

Fig. 6. Succession of the Lower Cretaceous deposits from the Semnelor Valley section.

\section{Urzicarilor Valley Section}

The Urzicarilor Valley represents the southernmost left tributary of the Peştişului Valley (Fig. 1). The lithological $\log$ (Fig. 7) consists of two types of sediments: carbonate and siliciclastic.

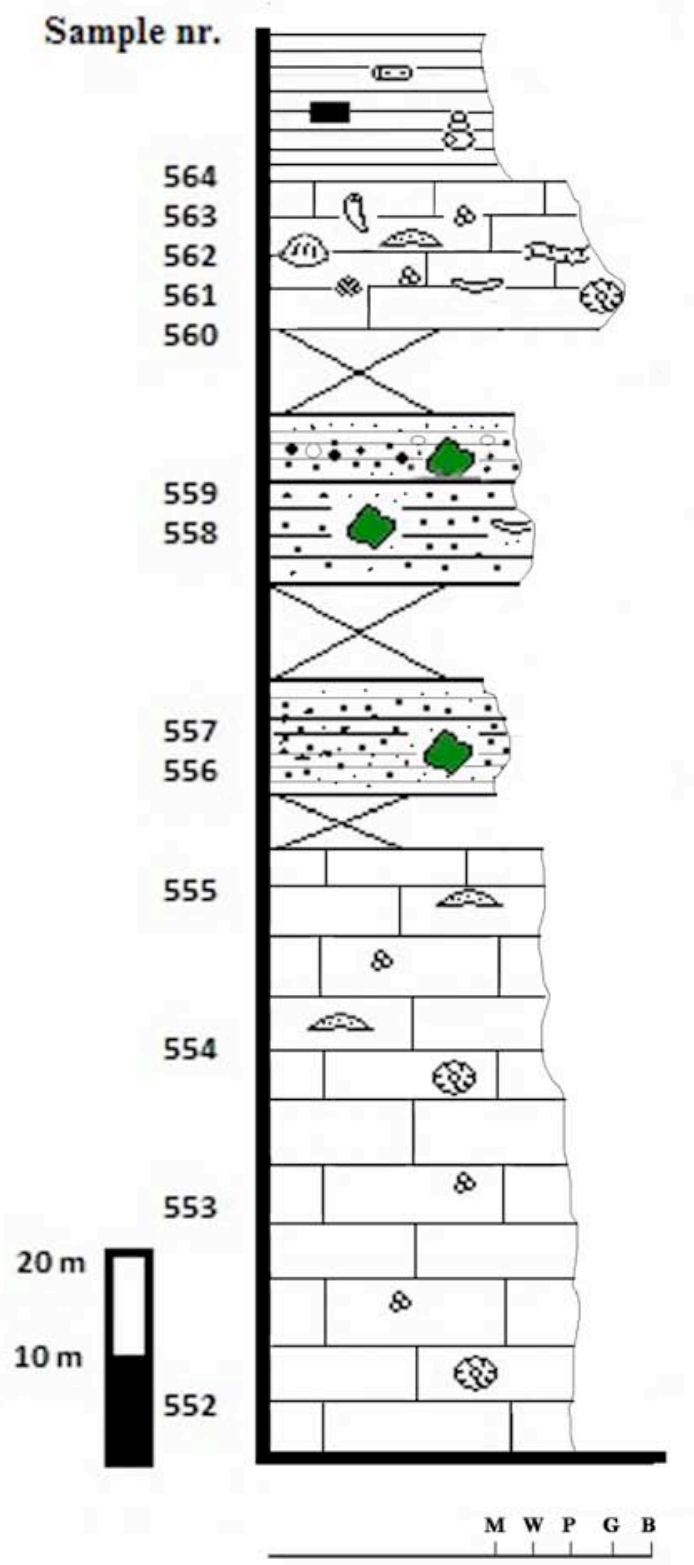

Fig. 7. Succession of the Lower Cretaceous deposits from the Urzicarilor Valley section.

The carbonate deposits occur at two levels. At the base, greyish limestones form decimetre- to metre-thick stratified beds that are rich in foraminifers and dasycladaleans. The main micofacies types are packstone (Pl. I, Fig. 7) and bioclastic wackestone/packstone (Pl. I, Fig. 4).

We have identified a micropaleontological association represented by Nezzazatinella sp., Novalesia producta (Magniez), Glomospira urgoniana Arnaud-Vanneau, Charentia cuvillieri Neumann (Pl. III, Fig. 5) Ammobaculites sp. (Pl. III, Fig. 2), Vercorsella sp. (Pl. III, Fig. 3), Gaudryina sp., Bolivinopsis sp., Paracoskinolina sp., Paleodictyoconus cuvillieri Foury, Sabaudia capitata Arnaud-Vanneau, abundant miliolids, Salpingoporella sp. and Bacinella-type structures. This association indicates a Lower Aptian age, thus the deposits are assigned to the Valea Măgurii Formation. 
The limestones in the top of the profile are darker in colour and consist of bioclastic grainstone/packstone with foraminifers, corals, gastropods and rudist fragments, dasycladaleans and red algae. Among the microfossils, we have identified Mesorbitolina texana (Roemer), Sabaudia minuta (Hofker), Polystrata alba (Pfender) and Salpingoporella sp. Accordingly, we assigned these limestones to the Vârciorog Formation.

The siliciclastic deposits are located in the median part of this section, between the two limestone levels, as well as on the top of the upper one. They are represented by sandstones and conglomerates interlayered with silty marls and silty marly clays.

\section{Arsurilor Valley Section}

The Arsurilor Valley represents a right tributary of the Peştişului Valley (Fig. 1). Calcareous deposits dominate the section along this valley, with subordinate siliciclastic interlayers (Fig. 8).

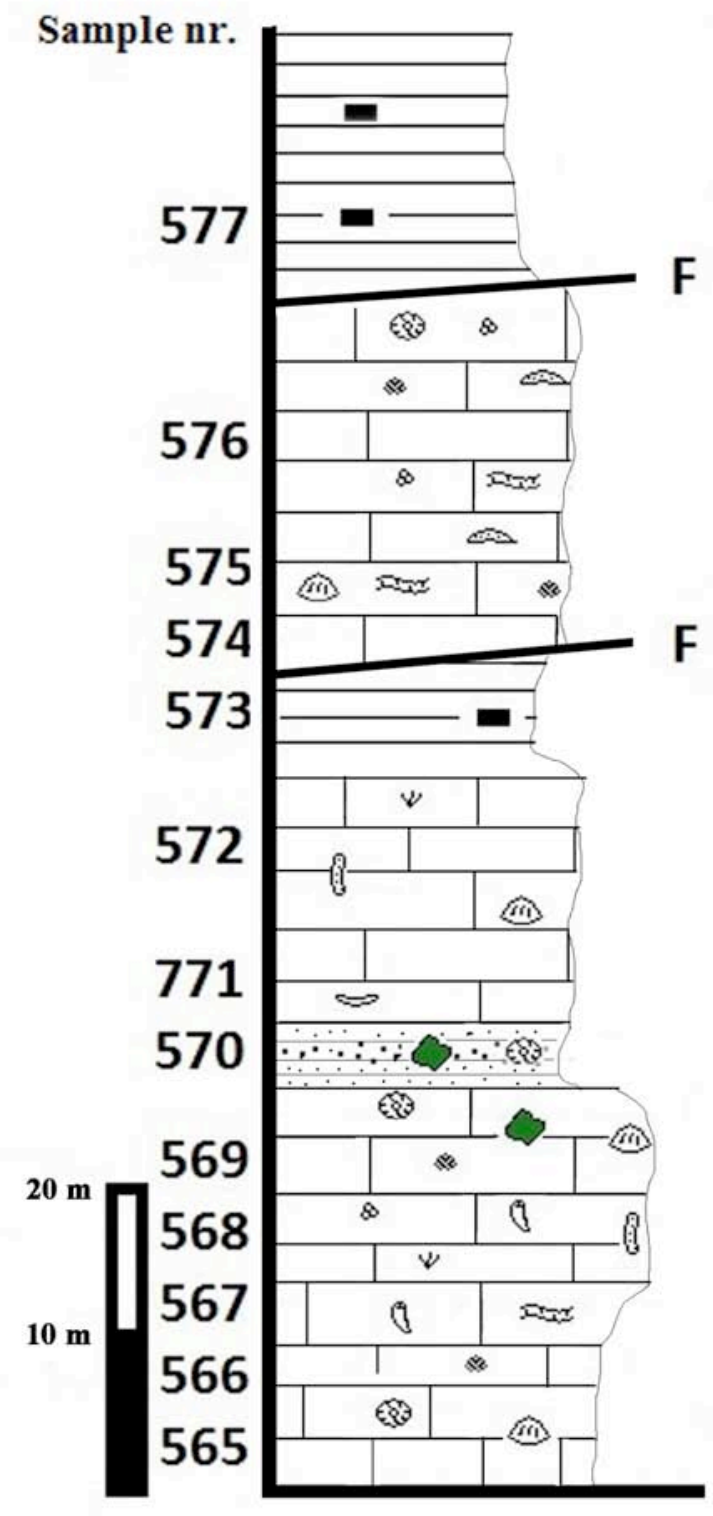

$\begin{array}{lllllllllllllll} & \text { M } & \text { W } & \mathbf{P} & \mathbf{G} & \mathbf{B}\end{array}$

Fig. 8. Succession of the Lower Cretaceous deposits from the Arsurilor Valley section.
The base of the section consists of blackish limestones, built up of bioclastic wackestone/packstone (Pl. I, Figs. 3, 5), bioclastic packstone/grainstone, bioclastic grainstone and coralgal bioconstructions. Benthic foraminifers, among which Mesorbitolina texana (Roemer), Charentia cuvillieri Neumann, and Nezzazatinella sp. abound in these deposits. Marinella lugeoni Pfender, sponges, and fragments of rudists and echinoderms are also present. The corals and sponges are encrusted by Bacinella-Lithocodium and by red algae [Polystrata alba (Pfender), (Pl. IV, Fig. 5)]. Based on both the micropaleontological association, and the presence of glauconite in the siliciclastic matrix, we assigned these deposits to the Vârciorog Formation.

A clayey-marly level crops out on the top of the blackish nodular limestones. The typical succession of the Vârciorog Formation is interrupted by two faults delimiting carbonate deposits. The micropaleontological association identified in these limestones consists of benthic foraminifers, dasycladalean algae, calcimicrobes and echinoderms. Among the foraminifers, we have identified Palorbitolina lenticularis (Blumenbach), Orbitolinopsis buccifer ArnaudVanneau, Mayncina sp. (P1. III, Fig. 6), Textularia sp., Charentia cuvillieri Neumann and Nezzazatinella sp. Miliolids are also numerous, while calcareous algae are represented by Salpingoporella sp. Based on this micropaleontological assemblage we assigned these limestones to the Valea Măgurii Formation (Lower Aptian).

\section{Section in the Upper part of Văsii Valley}

This section is located on the sidewall of county road 767 Dobreşti-Vârciorog, upstream of the Văsii Valley. The base of the succession consists of a thick marly horizon (Ecleja Marls) (Pl. I, Fig. 1). The marls are laminated, and are rich in plant remains and coal. Rare textulariid foraminifers and bivalve fragments were also found. The limestones on the top of the marls consist of bioclastic grainstone/packstone (Pl. I, Fig. 8) with numerous benthic foraminifers, including frequent orbitolinids. Additionally, dasycladaleans, corals, bivalves and gastropods are present. The micropaleontological association consists of Palorbitolina lenticularis (Blumenbach), Charentia cuvilieri Neumann, Vercorsella sp., Nezzazatinella sp., Bolivinopsis sp., miliolids and Salpingoporella sp. (Pl. III, Figs. 7,8 ), and is characteristic of the Valea Măgurii Formation.

A fault marks the limit between the Valea Măgurii Limestones and the glauconitic sandstones. The succession continues with detrital deposits (glauconitic sandstones, laminated marls with ammonite remains) interlayered within carbonate deposits (bioconstructed limestones in the base, followed by bioclastic packstone/grainstone). The presence of glauconitic sandstones, plant remains, marcasite nodules and the ammonites-bearing horizon in the siliciclastic interlayers are all typical features of the Vârciorog Formation. Additionally, the microfauna identified in the carbonate levels, rich in orbitolinids, mainly represented by Mesorbitolina texana (Roemer), and constitutes another characteristic for this formation. The bioconstructed limestone level also evidenced contains a calcareous algae association [Triploporella sp., Polystrata alba (Pfender), Sporolithon rude (Lemoine)] accompanied by Carpathoporella occidentalis Dragastan, Lithocodium aggregatum Elliott and Bacinella-type structures (P1. IV, Fig. 6). Other fossil remains are represented by corals, bryozoans, as well as fragments of rudists and gastropods. 
The other calcareous levels of Vârciorog Formation cropping out in this profile provided a foraminifer association consisting of Mesorbitolina texana (Roemer), Vercorsella sp., Gaudryina sp., ?Textularia sp., Sabaudia minuta (Hofker), Charentia cuvillieri Neumann Nezzazatinella sp., Lenticulina sp., Glomospira urgoniana Arnaud-Vanneau and miliolids.

Several faults separate the Vârciorog Formation into blocks. Among them, the most important fault is the one putting in contact the ammonites-containing marls, currently identified in the base of Vârciorog Formation only, with the stratigraphically younger orbitolinid-rich black limestones (Fig. 9).

\section{Sample nr.}

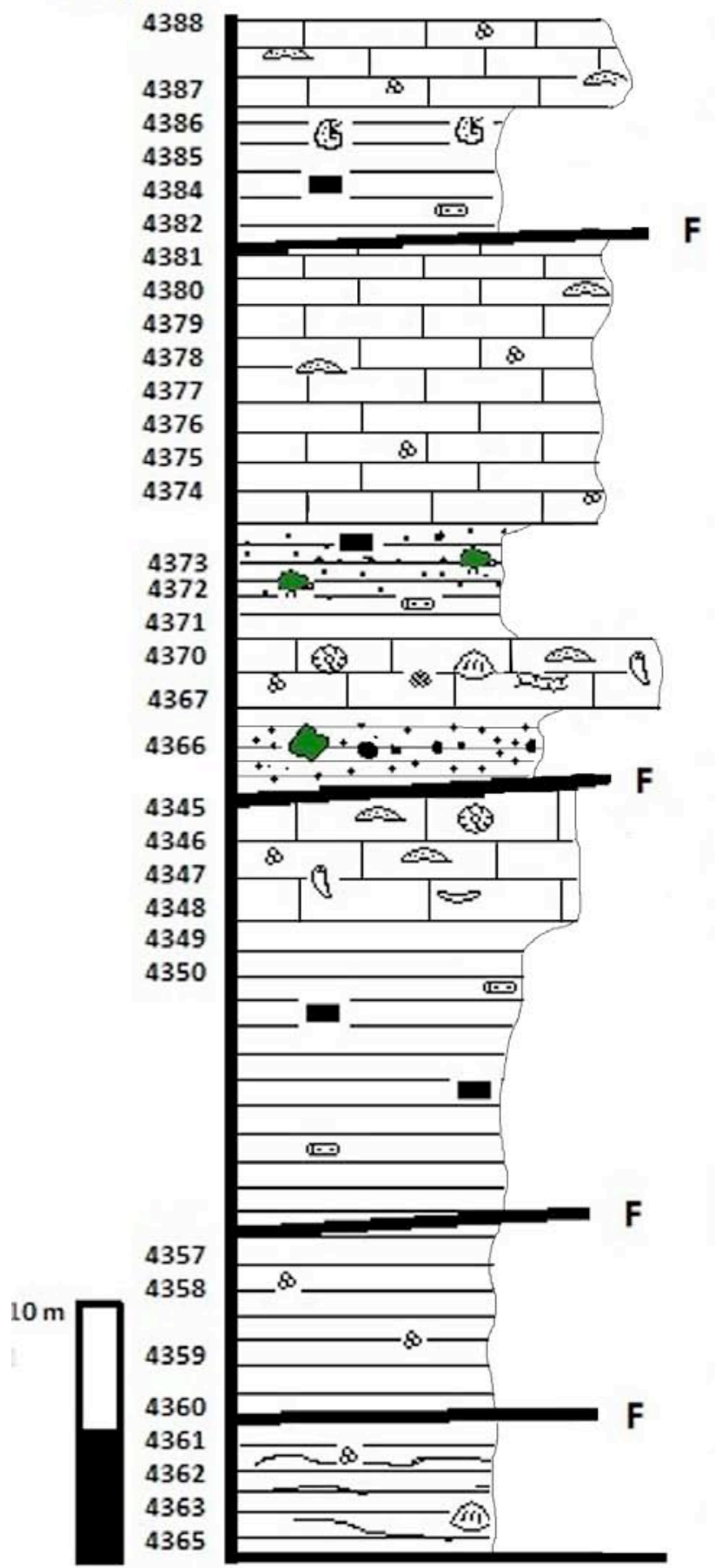

$\begin{array}{lllllllllllllll}\text { M } & \text { W } & \mathbf{P} & \mathbf{G} & \mathbf{B}\end{array}$

Fig. 9. Succession of the Lower Cretaceous deposits from the Vâsii Valley section.

Studia UBB Geologia, 2012, 57 (1), 33 - 51

\section{GENERAL SUCCESSION AND AGE OF THE SEDIMENTARY FORMATIONS}

Based on the detailed results provided by the sections presented above, we have constructed a general synthetic $\log$ of the studied area (Fig. 10). Three distinctive lithostratigraphical units were documented: the Ecleja Formation, the Valea Măgurii Formation, and the Vârciorog Formation.

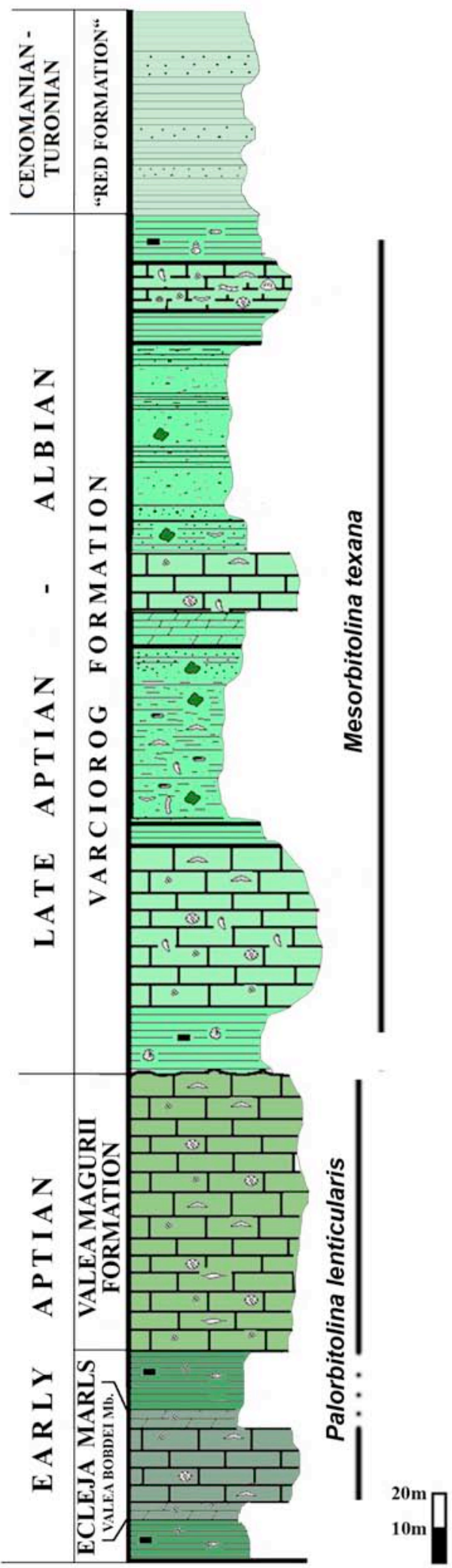

Fig. 10. Synthetic log with the Lower Cretaceous deposits from Varciorog-Dobreşti area. 
The marls of the Ecleja Formation crop out in the section measured near the hairpin curve of county road 767, in the upper part of the Văsii Valley. These greyish marls are laminated and contain large amounts of metamorphic clasts, mainly represented by micas and quartzites. Their lamination, parallel to the schistosity, is often marked by microstylolites (Pl. I, Fig. 1). In these deposits we have identified only rare foraminifers and plant remains (Pl. III, Fig. 1). Thus, the lack of index fossils prevents us from assigning an age to the marl level. Based on their stratigraphic location beneath the Valea Măgurii Limestones (upper Bedoulian), they can be assigned to the lower Aptian (lower Bedoulian, cf. Cociuba, 1999; Bucur and Cociuba, 2001).

The limestones belonging to the Valea Măgurii Formation occur in the sections along he Todii, Urzicarilor, Arsurilor and Văsii Valleys. Their early Aptian age was assigned by Cociuba

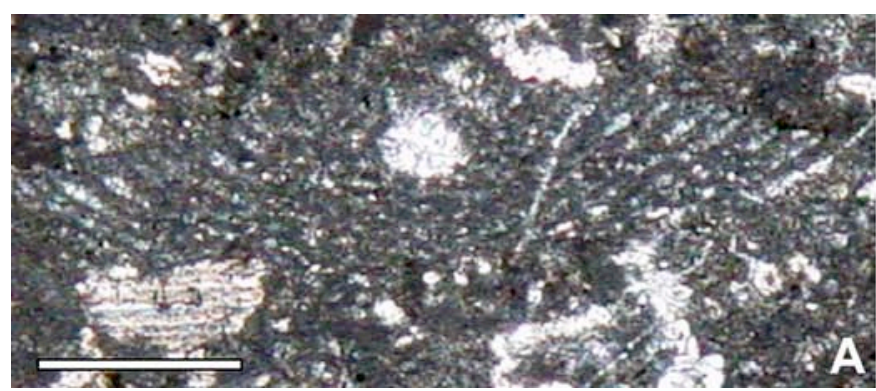

(1999) and later by Bucur and Cociuba (2001) based on the presence of the orbitolinids Palorbitolina lenticularis, Orbitolinopsis buccifer and Paleodictyoconus cuvillieri. Palorbitolina lenticularis (Blumenbach) is also present in the thin sections analysed (Fig. 11A)

The siliciclastic and carbonate deposits of the Vârciorog Formation cover most of the studied area. Their late AptianAlbian age is mainly advocated by the presence of the orbitolinid Mesorbitolina texana (Roemer) (Fig. 11B). This is also backed by the ammonite fauna described by Avram et al. (2001), assigned by the authors to the uppermost Bedoulian-lower Gargasian period, and considered as belonging to the Ecleja Formation. Nevertheless, this fauna belongs to the base of the Vârciorog Formation and not to the Ecleja Marls, as demonstrated by Cociuba (1999).

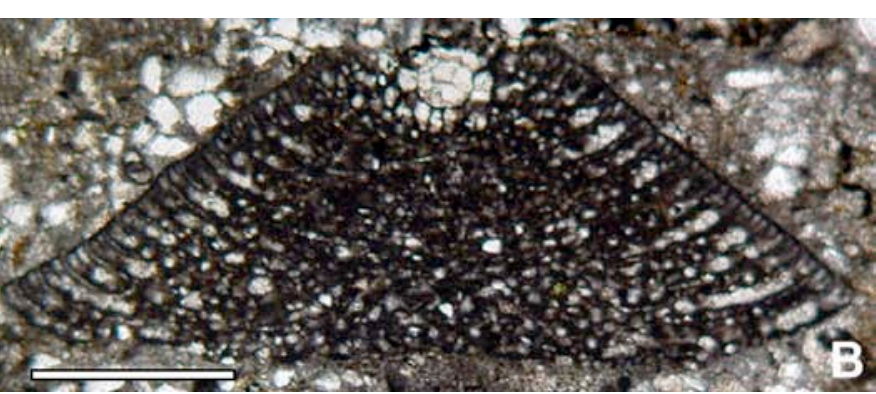

Fig. 11. The two index orbitolinid foraminifera, Palorbitolina lenticularis (Blumenbach) $(A)$ and Mesorbitolina texana $($ Roemer $)(B)$.

\section{DEPOSITIONAL ENVIRONMENTS}

Most probably, the Ecleja Marls were deposited in a (not very deep?) basin genetically connected to the regional tectonic movements at the end of the Barremian. At the same time, these events have caused the uplift of some adjacent areas, thus the reactivation of the landscape energy leading to an increased terrigenous supply (Bucur et al., 2010).

The microfacies features and the micropaleontological associations indicate that the calcareous deposits of the Valea Măgurii Formation formed in a normal marine environment. The products of both the shallow subtidal and the intertidal zones can be observed, the latter one being represented by fenestral fabrics (P1. I, Fig. 2). A karstic paleolandscape developed in the top of the formation, with ferruginousbauxitic deposits present as films, nests or lenses filling small cavities on the surface of the limestones, or in veins. These features point out that the limestones were temporarily subjected to subaerial exposure, followed by the transgressive and unconformable deposition of the marls in the base of Vârciorog Formation.

The presence of two types of deposits identified along the Vârciorog Formation succession, i.e., siliciclastics and carbonates, documents the existence of diverse successive environments alternatively developed in the sedimentary basin.

The siliciclastic deposits represent submarine fan deltas that accumulated in the marginal areas of the basin. Based on the contained bioclasts, we estimate a normal marine environment of formation. Nevertheless, the various sources, or the shape and size of the clasts in the conglomerates suggest an alluvial-fluviatile source area and accumulation in proximal areas of the marine shelf. This explains the mixing of typical marine bioclasts with pebbles originating from the alluvial-fluviatile fans discharging towards the shelf margin.
Regarding the unchannelled sedimentary bodies with tabular and layered geometries, the identified sedimentary structures and their association with conglomerates or clays, indicate that these bodies were generated by turbiditic flows.

The siliciclastic bodies have produced positive topographies at the basin margin, thus providing favourable conditions for the subsequent accumulation of carbonate deposits. Bioconstructions and open-shelf carbonate deposits (bioclastic packstone-grainstone) have formed on the surface of these highlands. Small bioconstructions initiated by corals and rudists, either solitary or forming little clusters could develop in this shallow marine normal environment with low hydrodynamics and favourable bioclastic substrate. The internal sediment, represented by bioclastic wackestone/ packstone, of the bioconstructions and the encrustations on the fragments of corals and rudists produced by various organisms indicate low sedimentation rates, favourable for the bioconstructions' installation and development. On the other hand, the sporadic freshwater supply from the continent must have inhibited their excessive development.

A large part of the carbonate sediments of Vârciorog Formation was deposited by gravity flow processes, from the marginal areas where genuine carbonate platforms might have existed (e.g. Aştileu-Subpiatră, Bucur et al., 2008) towards the more distal parts of the basin.

Based on the siliciclastic facies types, we can recognize several "coarsening upward" cycles. These record a transition from pro-delta clays in the lower part of the succession to delta front turbiditic sandstones/boulders, as a feature of the progradation of alluvial fans towards the basin. The subsequent accumulation of the carbonate deposits took place as a result of an increase of relative sea level and of the stability of the basin margin stability that lead to the regression of the alluvial fans. The delta fans in the Vârciorog Formation have evolved within the meso-Cretaceous tectogenesis framework, which determined the reactivation of 
the marginal areas of the basin. When the basin's border became active, siliciclastic deposits, progressively thicker upwards, started to form dominated by the coarse fraction ("coarsening upward" sequences).

\section{SEDIMENTARY EVOLUTION}

Tectonic movements became more intense at the end of the Barremian, leading to the fragmentation of the platform, with the generation of several blocks with distinctive vertical trends. In the northern part of the Pădurea Craiului Mountains, the accumulation of a breccia deposited in a subaerially exposed environment was favoured by the oscillating movements of these blocks (Gugu Breccia Member), resulting in horsts and graben structures (Patrulius et al., 1982; Cociuba, 1999).

Towards the end of the Bedoulian, such a tectonic event has triggered the installation of protected inner depositional environments on large areas, similar to those deposited during the Barremian. This particular event resulted in the accumulation of the limestones of the Valea Măgurii Formation, which document a short emersion stage towards their top (Cociuba, 1999).

Starting with the Gargasian, terrigenous detrital sedimentation became more consistent, as a result of the reactivation of the landscape in the land areas. The contribution of the terrigenous supply increased, while the calcareous interlayers consisting of nodular limestones became thinner. Thus, the whole Vârciorog Formation displays "flysch"-type features. After the Albian this process intensified, with the formation of the "red formation" deposits. The clayey red deposits document the strengthening of the continental influence following the setup of the overthrust nappes. In the Northern Apuseni Mountains, the overthrusting lasted till the middle Turonian.

\section{CONCLUSIONS}

The detailed study of six geological sections in the Vârciorog-Dobreşti area (NW of Pădurea Craiului Mountains) has focussed on three sedimentary formations: the Ecleja Marls Formation, the Valea Măgurii Limestones Formation, and the Vârciorog Formation; the latter has a mixed, carbonatic-siliciclastic character.

The age of the three formations spans the early Aptian (Ecleja Marls and Valea Măgurii Limestones, as indicated by certain species of orbitolinids, especially by Palorbitolina lenticularis) and the late Aptian-Albian (Vârciorog Formation with a Gargasian ammonite fauna in the base and contains the orbitolinid Mesorbitolina texana) intervals.

The deposits of the Vârciorog Formation, which cover most of the study area, mainly formed by gravity flow processes. Some carbonate bioconstrucions formed in-situ, on the surface of highlands built of the subjacent siliciclastic deposits. The inner sediment (bioclastic wackestone/ packstone) of the bioconstructions and the encrustations produced by various organisms on corals and rudists document very low sedimentation rates. We assume that the installation of higher sedimentary rates, recorded by the lack of encrusting organisms, and the sporadic input of freshwater from the continent have led to an enforced constraint on the further development of bioconstructions.

Studia UBB Geologia, 2012, 57 (1), 33 - 51
Acknowledgments. This study is part of the project: Investing in people! $\mathrm{PhD}$ scholarship, Project co-financed by the Sectoral Operational Programme Human Resources Development 2007 - 2013 Priority Axis 1 "Education and training in support for growth and development of a knowledge based society" Key area of intervention 1.5: Doctoral and post-doctoral programmes in support of research. Contract POSDRU 6/1.5/S/3 - „Doctoral Studies: Through Science Towards Society" Babeş-Bolyai University, Cluj-Napoca, Romania (D.F. Lazăr). Part of the research was undertaken within the framework of the CNCSIS project ID59 (I. Cociuba). We thank the reviewers, Felix Schlagintweit and Mike Kamiski for their remarks and corrections.

\section{R E F E R E N C E S}

Avram, E., Antonescu, E. \& Melinte, M. 1996, Paleontological atlas of the Lower Cretaceous. Anuarul Institutului Geologic al României, 69 (1): 125-129 (in Romanian).

Avram, E., Bordea, S. \& Cociuba, I. 2001, Ammonite assemblages of the Ecleja Formation (Northern Apuseni Mts., Romania). Romanian Journal of Stratigraphy, 79: 13-20.

Bleahu, M., Istocescu, D. \& Diaconu, M. 1971, PreNeogene formations from the western part of the Apuseni Mountains and their structural position. Dări de Seamă, Institutul Geologic, LVII (1969-1970) (5): 5-21 (in Romanian).

Bordea, S., Istocescu, D. 1970, Contributions to the stratigraphical study of the Cretaceous (NeocomianTuronian) from the western part of Pădurea Craiului Mountains. Dări de Seamă, Institutul Geologic, LV (1967-1968) (4): 49-58 (in Romanian).

Bucur, I.I. 1981a, Pseudoactinoporella silvaeregis n. sp. in the Lower Cretaceous limestone from Pădurea Craiului (Apuseni Mountains). Revue Roumaine de Géologie, Géophysique et Géographie, série Géologie, 25: 151-153.

Bucur, I.I. 1981b, Algues calcaires du Cretacé inférieur des Monts Pădurea Craiului. Nymphaea, VIII-IX: 53-68.

Bucur, I.I. 1985, A new dasycladacean alga in the Urgonian limestones from Pădurea Craiului (Apuseni Mountains): Salpingoporella patruliusi n. sp. Revue Roumaine de Géologie, Géophysique et Géographie, série Géologie, 29: 81-84.

Bucur, I.I. 1988, Sur la présence de Juraella bifurcata (Algues calcaires, Udoteacées) dans les depôts du Cretacé inférieur des Monts Pădurea Craiului. Studia UBB Geologia-Geographia, XXXIII (1): 47-50.

Bucur, I.I. 1992, Revised description of some dasyclad species from the Romanian Lower Cretaceous. Revue de paléobiologie, 11 (2): 447-461.

Bucur, I.I. 1995, Algues calcaires dans les depôts du Jurassique supérieur-Cretacé inférieur des Monts Pădurea Craiului. Studii şi Cercetări, Muzeul BistriţaNăsăud, 1: 79-89.

Bucur, I.I. 2000, Lower Cretaceous Dasyclad algae from the Pădurea Craiului Massif (northern Apuseni Mountains, Romania). In Acta Palaeontologica Romaniae (Bucur, I.I., Filipescu, S., Eds.), Cluj University Press, Cluj-Napoca, 2: 53-72.

Bucur, I.I., Cociuba, I. 1996, Microbiostratigraphic markers in the Lower Cretaceous deposits from Pădurea Craiului (northern Apuseni Mountains). The 90 ${ }^{\text {th }}$ Anniversary 
Conference of the Geological Institute of Romania, Anuarul Institutului Geologic al României, 69 (Suppl. 1): 40-42.

Bucur, I.I., Cociuba, I. 1998, La plate-forme carbonatée du Cretacé inférieur des Monts Pădurea Craiului (Monts Apuseni, Roumanie). Biostratigraphie et configuration. Studia UBB Geologia, 43 (2): 89-96.

Bucur, I.I., Cociuba, I. 2001a, Upper Jurassic-Lower Cretaceous deposits from Pădurea Craiului. In Algae and carbonate platforms in the western part of Romania, $4^{\text {th }}$ Regional Meeting of IFAA, Cluj-Napoca, Romania, August 29-September 5, 2001. Field trip Guide Book (Bucur, I.I., Filipescu, S. \& Săsăran, E., Eds.). Cluj University Press, Cluj-Napoca, p. 40-49.

Bucur, I.I., Cociuba, I. 2001b, Lower Cretaceous algae of Pădurea Craiului. In Algae and carbonate platforms in the western part of Romania. $4^{\text {th }}$ Regional Meeting of IFAA, Cluj-Napoca, Romania, August 29-September 5, 2001. Field trip Guide Book (Bucur, I.I., Filipescu, S. \& Săsăran, E., Eds.). Cluj University Press, Cluj-Napoca, p. 117-126.

Bucur I.I., Cociuba I. \& Cociuba M. 1993, Microfacies and microfossils in the Upper Jurassic-Lower Cretaceous limestone in the southern part of the Pădurea Craiului Mountains. Romanian Journal of Stratigraphy, 75: 33-40

Bucur, I.I., Săsăran, E., Cociuba, I., Lazăr, D.F. \& Neacşu, M.V. 2008, Complementary research on the Valea Măgurii Formation in Varciorog area (Pădurea Craiului, Apuseni Mountains). In Contributions to the scientific Session I.P.Voiteşti (Bucur, I.I., Filipescu, S., Eds.), Cluj University Press, Cluj-Napoca, p. 5-8.

Bucur, I.I., Săsăran, E., Balica, C., Beleş, D., Bruchental, C., Chendeş, C., Chendeş, O., Hosu, A., Lazăr, D.F., Lăpădat, A., Marian, A.V., Mircescu, C., Turi, V. \& Ungureanu, R. 2010, Mesozoic carbonate deposits from some areas of the Romanian Carpathians - case studies. Cluj University Press, Cluj-Napoca, 203 p.

Cociuba, I. 1995, Foraminifèrs benthique dans les dépôts du Jurassique supérieur et du Cretacé inférieur des Monts Pădurea Craiului. Studii şi Cercetări, Muzeul BistriţaNăsăud, 1: 119-314.

Cociuba, I. 1997, The presence of the foraminifer Alveosepta jaccardi (Schrodt) in the Upper Jurassic limestone of Pădurea Craiului Mountains. In Acta Palaeontologica Romaniae (Dragastan, O., Ed.), 1, p. 221-225.

Cociuba, I. 1999, Stratigraphical study of the Mesozoic deposits from the South-Western part of Pădurea Craiului (in Romanian). Unpubl. PhD Thesis, University Babeş-Bolyai, Cluj-Napoca, Romania, 253 p.

Cociuba, I. 2000, Upper Jurassic-Lower Cretaceous deposits in the south-western part of the Pădurea Craiului. Formal lithostratigraphic units. Studia UBB Geologia, 45 (2): 33-61.

Dragastan, O. 1966, Upper Jurassic and Lower Cretaceous microfacies from the Apuseni Mountains (Trascău and Pădurea Craiului Mountains). Analele Universităţii Bucureşti, 15 (2): 100-113 (in Romanian).

Dragastan, O. 1999, Jurassic-Cretaceous calcareous algae of the Transylvanides, Inner Dacides and Moesian Platform (Romania). Revista Española de Micropaleontologia, 31 (2): 185-218.
Dragastan, O., Ciobanu, C. 2002, New calcareous algae (Bryopsidophyceae) from the Blid Formation (Berriasian-Early Aptian) of the Southern Brusturi sector (Apuseni Mts.) and some new litho- and biostratigraphical data. In Studia UBB Geologia, Special Issue 1 (Baciu, I., Bucur, I.I., Filipescu, S. \& Săsăran, E., Eds.), Cluj University Press, Cluj-Napoca, p. 165-188.

Dragastan, O., Coman, M. \& Stiucă, E. (1988), Bauxitebearing formations and facies in the Pădurea Craiului and Bihor Mountains (Northern Apuseni). Revue Roumaine de Géologie, Géophysique et Géographie, série Géologie, 32: 67-81.

Dragastan, O., Purcel, R. \& Brustur, T. 1986, The Upper Jurassic and Lower Cretaceous formations from the Bihor Mts.-Central Southern sector/Northern Apuseni. Analele Universităţii Bucuresti, 35: 57-70.

Fisch, W. 1924, Beiträge zur Geologie des Bihargebirges. Jahresbericht der Philosophiche Fakultät der Universität Bern, IV: 114-135.

Ianovici, V., Borcoş, M., Bleahu, M., Patrulius, D., Lupu, M., Dimitrescu, R. \& Savu, H. 1976, Geology of the Apuseni Mountains. Editura Academiei R.S.R., Bucureşti, $631 \mathrm{p}$ (in Romanian).

Istocescu, D. 1970, The stratigraphy and fauna of the Cretaceous deposits from Vârciorog - Copăcel area. Dări de Seamă, Institutul Geologic, LIV (4): 161-164.

Istocescu, D., Mihai, A., Diaconu, M. \& Istocescu, F. 1970, Geological study of the region between the Crişul Negru and Crişul Repede rivers. Dări de Seamă, Institutul Geologic, LV (1967-1968) (5): 89-106 (in Romanian).

Kräutner, T. 1939, Die geologischen Verhältnisse des östlichen Teiles des Pădurea Craiului. Bulletin de la Société Roumaine de Géologie, IV: 73-90.

Kräutner, T. 1941, Études géologiques dans la Pădurea Craiului. Comptes Rendus de l'Institut Géologique, XXV (1936-1937): 145-156.

Patrulius, D. 1956, Contributions to the geological study of Pădurea Craiului (preliminary note). Dări de Seamă, Comitetul Geologic, XL: 116-127 (in Romanian).

Patrulius, D., Bordea, S. \& Avram, E. 1982, La brèche de Gugu - un exemple de contrôle téctonique de la sédimentation sur une plate-forme carbonatée barrémobedoulienne (Pădurea Craiului - Monts Apuseni). Dări de Seamă ale Institutului de Geologie şi Geofizică, LXVI (4): 109-117.

Popa, E. 1981, La biostratigraphie des formations mézozoique de la partie orientale de Pădurea Craiului (Monts Apuseni). Anuarul Institutului de Geologie şi Geofizică, LVIII: 203-282.

Preda, I. 1963, The geology of the Lunca Sprie-CorbeştiValea Râului-Surducel region. Societatea de Ş tiinţe Naturale şi Geografice din R.P.R., Comunicări de Geologie, II: 197-204.

Răileanu, G. 1956, Geological research of the Roşia region (Pădurea Craiului Mountains. Analele Universităţii C.I. Parhon, 12: 213-226 (in Romanian).

Szontagh, T. 1904, Geological study of the Vadu CrişuluiCălățea-Valea Vida region (Pădurea Craiului). A Magyar Királyi Földtani Intézet évi jelentés, 1903, p. 58-64 (in Hungarian). 
Plate I. Microfacies of the Lower Cretaceous deposits from the Ecleja and Valea Măgurii formations. Photomicrographs. Scale bar is $1 \mathrm{~mm}$.

Fig. 1. Marly siltites with stylolites, sample 4360 (Ecleja Formation,Văsii Valley section).

Fig. 2. Fenestral mudstone with some scattered miliolids, sample 450 (Valea Măgurii Formation, Todii Valley section).

Figs. 3, 4, 5. Bioclastic wackestone/packstone with foraminifers (Orbitolinopsis sp, Textularia sp., Mayncina sp.), 3, 5 sample 575 (Valea Măgurii Formation, Arsurilor Valley section); 4, sample 555 (Valea Măgurii Formation, Urzicarilor Valley section).

Fig. 6. Peloidal-bioclastic packstone/grainstone rich in miliolids, sample 454 (Valea Măgurii Formation, Todii Valley section).

Fig. 7. Bioclastic packstone, sample 552 (Valea Măgurii Formation, Urzicarilor Valley section).

Fig. 8. Bioclastic grainstone with orbitolinids, sample 4347 (Valea Măgurii Formation, Văsii Valley section). 

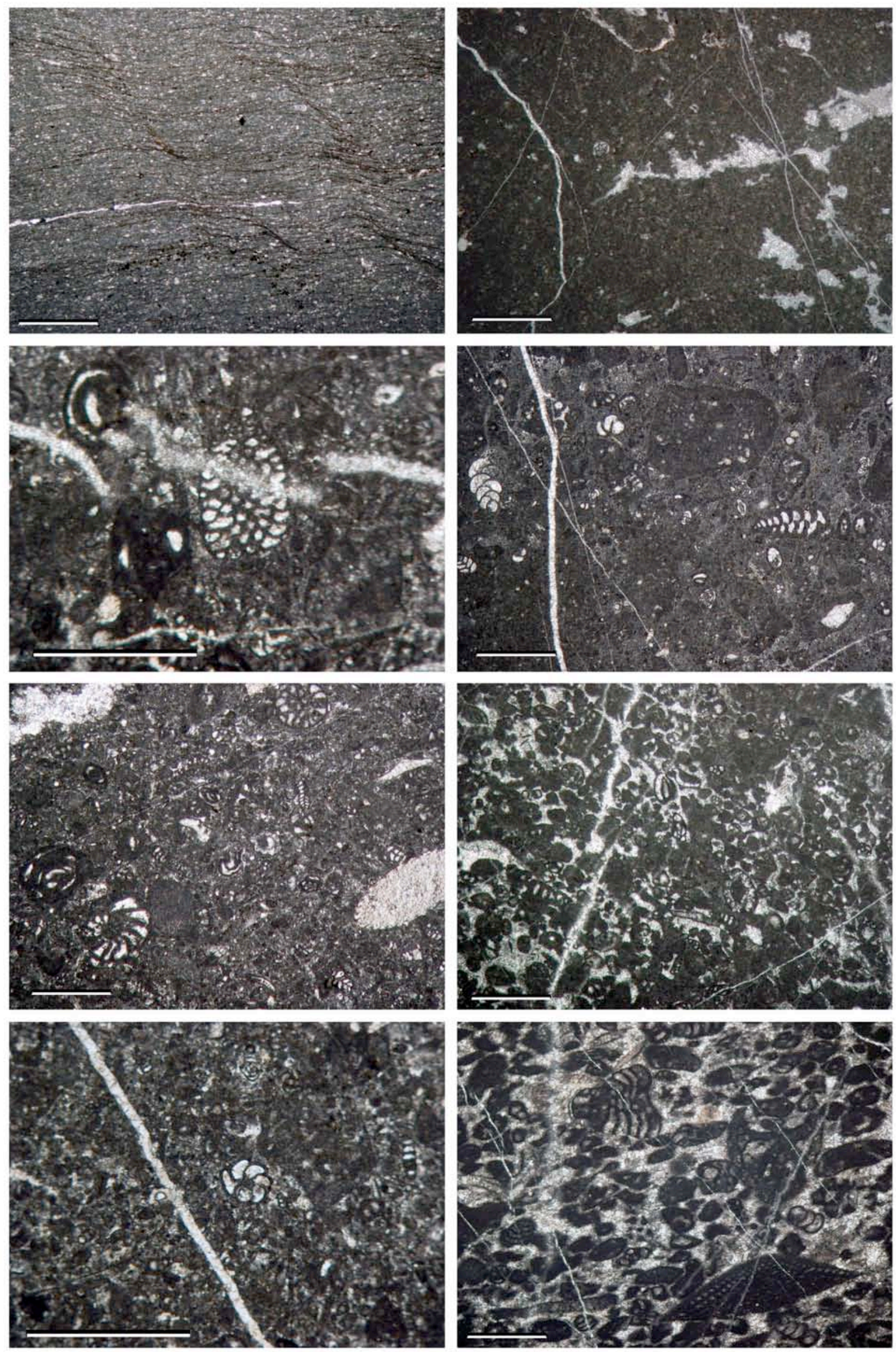
Plate II. Microfacies of the Lower Cretaceous deposits from the Vârciorog Formation. Photomicrographs. Scale bar is $1 \mathrm{~mm}$.

Fig. 1. Bioclastic wackestone with orbitolinids and Charentia cuvillieri Neumann, sample 449 (Toanghii Valley section). Fig. 2. Bioclastic packstone with worm tubes, sample 471 (Todii Valley section).

Figs. 3, 4. Corals, rudists, and orbitolinids-bearing grainstone; in the lower right-side of Fig. 3 a longitudinal section of Carpathocancer? plassenensis (Schlagintweit \& Gawlick) is visible; 3, sample 600 (Todii Valley section); 4, sample 438 (Toanghii Valley section).

Figs. 5, 6. Boundstone with corals and sponges; 5, sample 597 (TodiiValley section), 6, sample 393 (Semnelor Valley section). Figs. 7, 8. Bioclastic sandstones with Mesorbitolina texana (Roemer) (7) and rudists fragments (8), samples 484 and 476, respectivelly (Todii Valley section). 

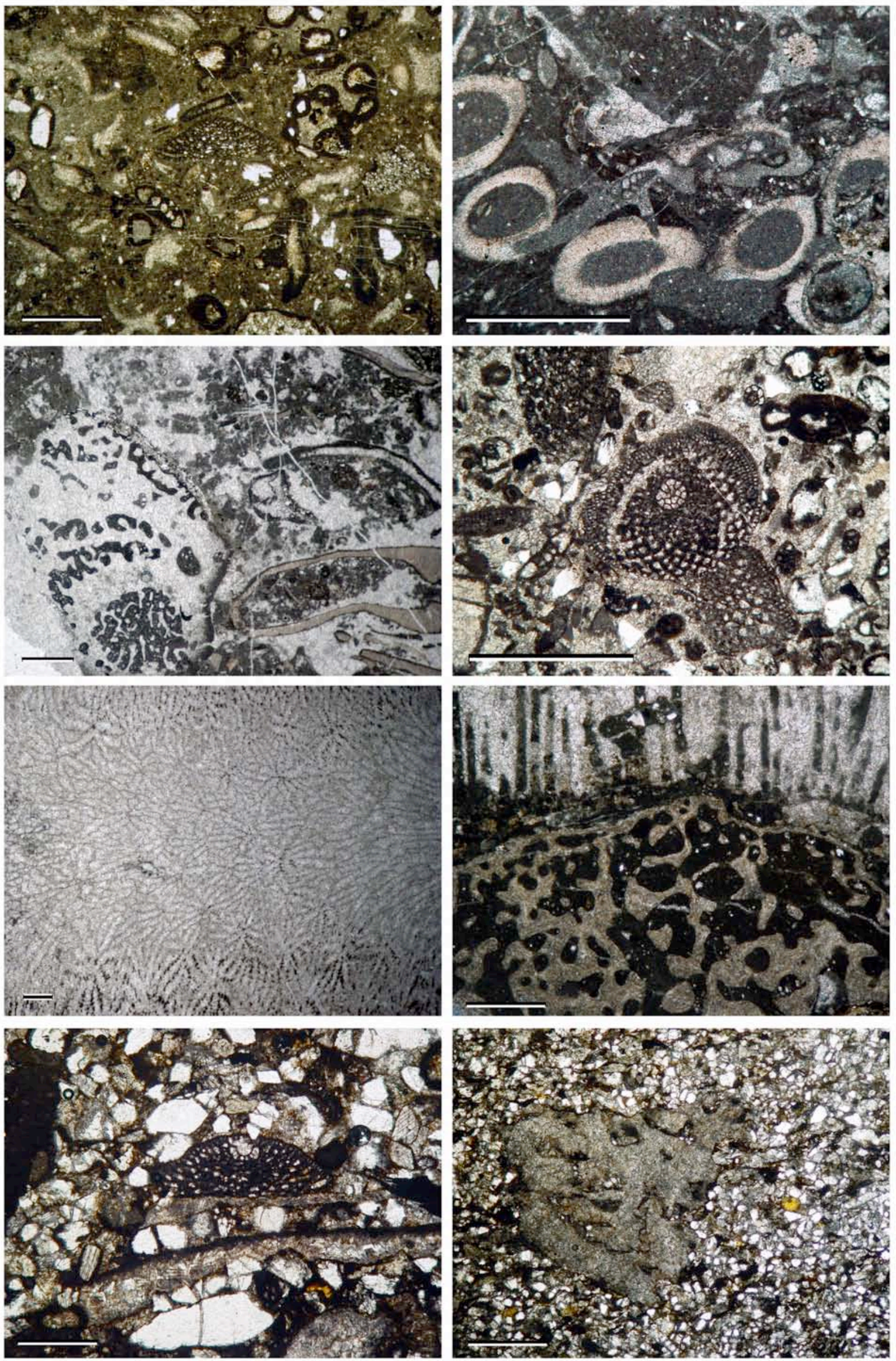
Plate III. Microfossils from the Ecleja and Valea Măgurii formations. Photomicrographs. Scale bar is $1 \mathrm{~mm}$.

Fig. 1. Unidentified foraminifer, sample 4358 (Ecleja Formation, Văsii Valley section).

Fig. 2. Ammobaculites sp., sample 555 (Valea Măgurii Formation, Urzicarilor Valley section).

Fig. 3. ?Arenobulimina sp., sample 451 (Valea Măgurii Formation, Todii Valley section).

Fig. 4. Vercorsella sp., sample 552 (Valea Măgurii Formation, Urzicarilor Valley section).

Fig. 5. Charentia cuvilieri, sample 553 (Valea Măgurii Formation, Urzicarilor Valley section).

Fig. 6. Mayncina sp., sample 575 (Valea Măgurii Formation, Arsurilor Valley section).

Figs. 7, 8. Salpingoporella melitae Radoičić (7) and Salpingoporella muehlbergi (Lorenz) (8), sample 4347 (Valea Măgurii Formation, Văsii Valley section). 

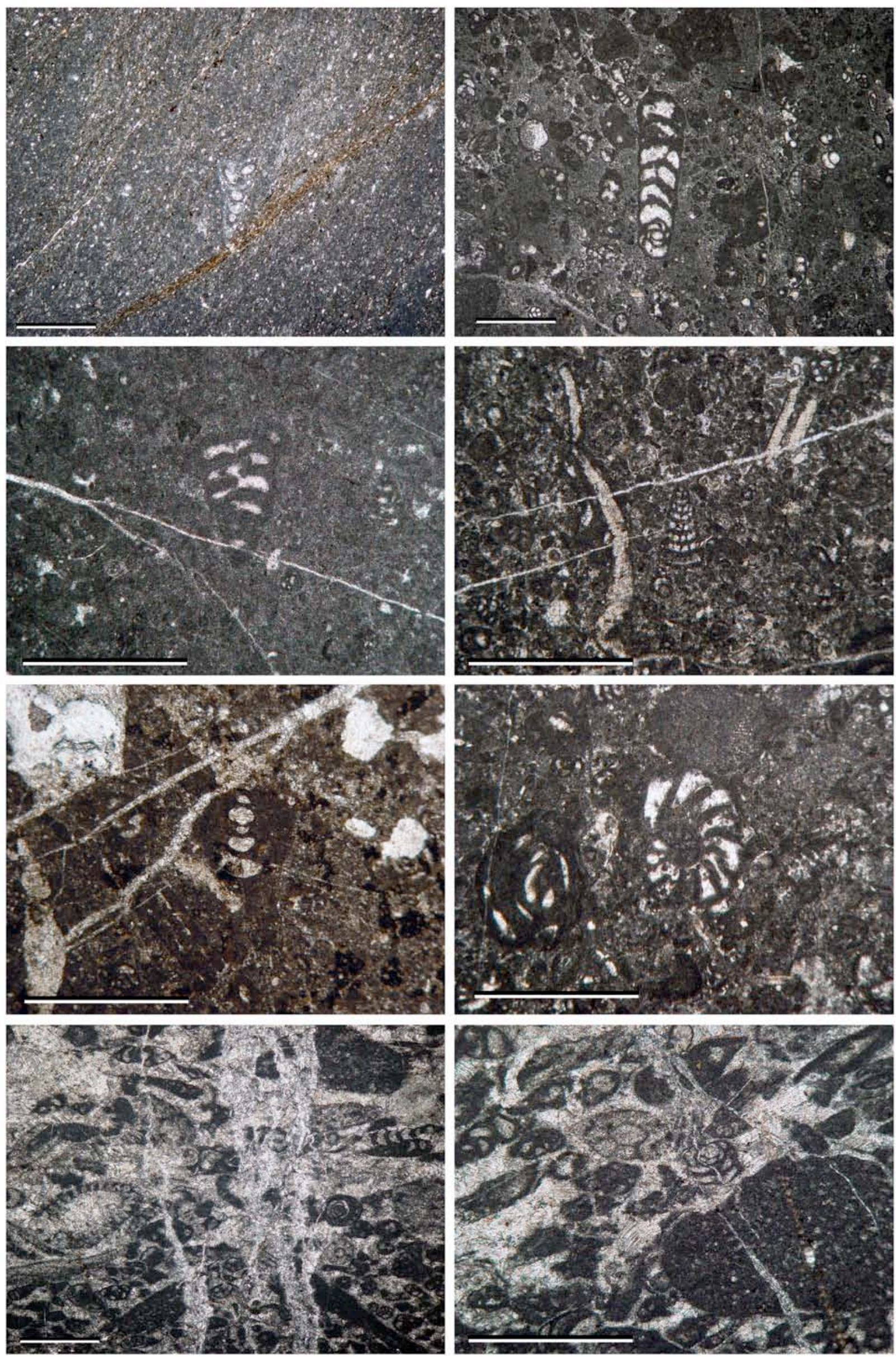
Plate IV. Microfossils from the Vârciorog Formation. Photomicrographs. Scale bar is $1 \mathrm{~mm}$.

Fig. 1. Carpathoporella occidentalis (Dragastan), sample 600 (Todii Valley section).

Fig. 2. Triploporella sp., sample 602 (Todii Valley section).

Fig. 3. Marinella lugeoni Pfender, sample 438 (Toanghii Valley section).

Fig. 4. ?Dobrogelina sp., sample 420 (Semnelor Valley section).

Fig. 5. Coral incrusted by Polystrata alba (Pfender), sample 568 (Arsurilor Valley section).

Fig. 6. Bacinella irregularis Radoičić, sample 4367 (Văsii Valley section).

Fig. 7. Lenticulina sp., sample 412 (Semnelor Valley section).

Fig. 8. Mesorbitolina texana (Roemer), sample 622 (Todii Valley section). 

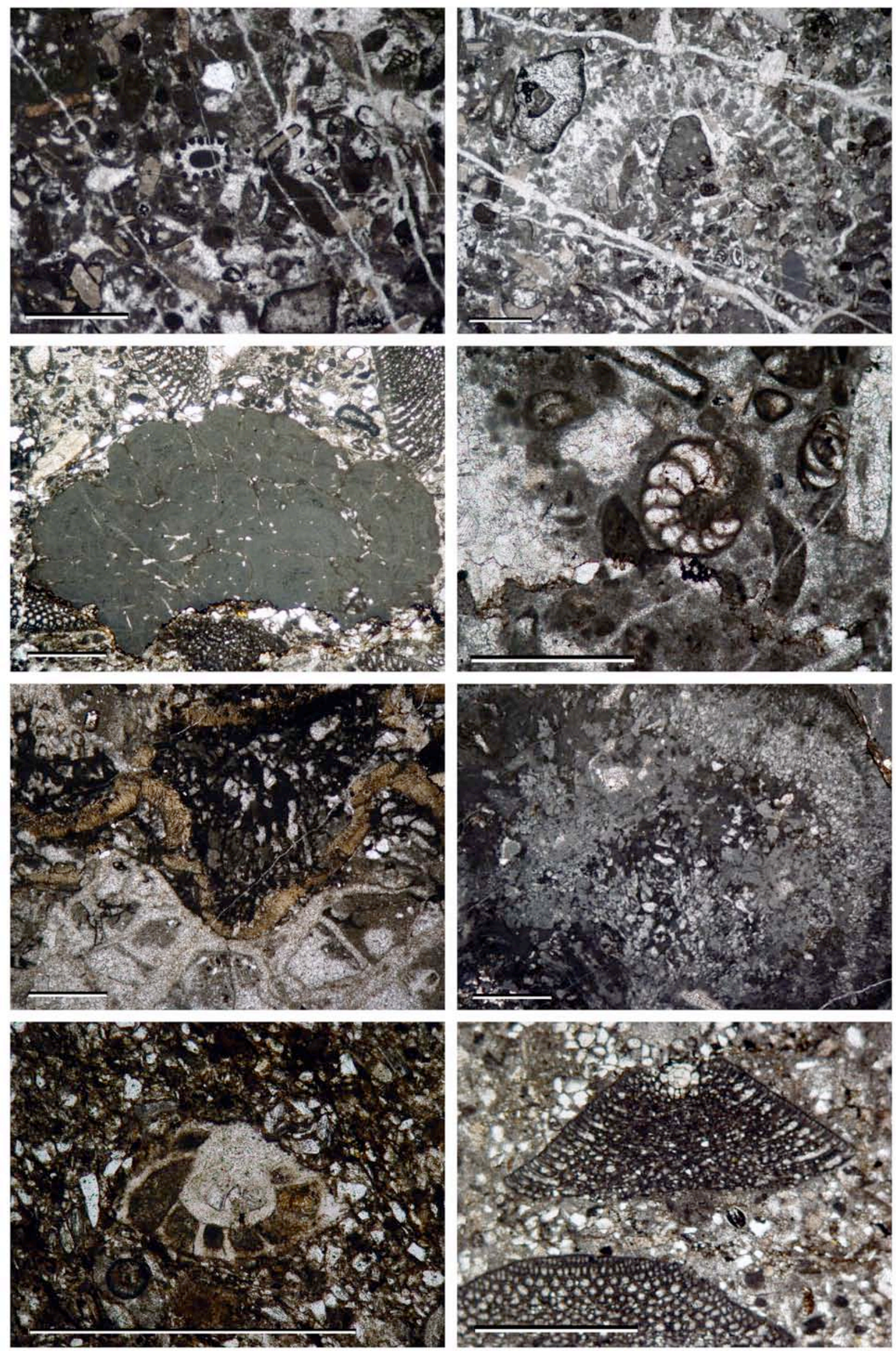